Research Article

\title{
Genotoxic evaluation of the River Paranaíba hydrographic basin in Monte Carmelo, MG, Brazil, by the Tradescantia micronucleus
}

\author{
Carlos F. Campos ${ }^{1,3}$, Boscolli B. Pereira ${ }^{2}$, Edimar O. de Campos-Junior ${ }^{3}$, Eduardo F. Sousa ${ }^{1}$, \\ Henrique N. Souto ${ }^{1}$ and Sandra Morelli ${ }^{3}$ \\ ${ }^{1}$ Departamento de Biologia Celular, Fundação Carmelitana Mário Palmério, Monte Carmelo, MG, Brazil. \\ ${ }^{2}$ Instituto de Geografia, Universidade Federal de Uberlândia, Uberlândia, MG, Brazil. \\ ${ }^{3}$ Instituto de Genética e Bioquímica, Universidade Federal de Uberlândia, Uberlândia, MG, Brazil.
}

\begin{abstract}
Pollutants have adverse effects on human health and on other organisms that inhabit or use water resources. The aim of the present study was to assess the environmental quality of three watercourses in Monte Carmelo, MG, Brazil, using the micronucleus test on Tradescantia. For each treatment, 15 plants were exposed to water samples for $24 \mathrm{~h}$. The control group was exposed to formaldehyde $(0.2 \%)$ and the negative control to Hoagland solution. Subsequently the plants were placed in Hoagland solution for $24 \mathrm{~h}$ to recover. Cells were stained with $2 \%$ acetic carmine and examined by light microscopy. Three hundred tetrads were analyzed per slide. The frequency of genotoxic alterations was expressed as the number of micronuclei per 100 tetrads, and the groups were compared by ANOVA. At all sample sites for each watercourse significant genotoxicity indices were observed. The results suggest that in the Mumbuca creek, the current situation of effluent discharge should be reconsidered by the municipal environmental authorities. The increase in micronucleus frequency denoted for water samples of the Mumbuca creek, Lambari river and Perdizes river emphasizes the need to adopt environmental vigilance strategies, such as biological monitoring.
\end{abstract}

Keywords: biomonitoring, genotoxicity, micronucleus, Tradescantia pallida.

Received: May 9, 2015; Accepted: July 21, 2015.

\section{Introduction}

The World Health Organization (WHO) states that water is essential to sustain life, and is a substance that should necessarily be available to all in adequate, safe and accessible form. Improving access to potable water of appropriate quality is fundamental to health throughout lifetime. Thus microbiological antisepsis, chemicals, radiological compounds, flavor, odor, appearance parameters and catchment systems, treatment and distribution should be monitored periodically to guarantee an adequate water quality control (WHO, 2011).

Resolution $N^{\circ} 357$ of 2005, of the Brazilian National Environment Council (CONAMA) establishes water quality standards in virtue of substance concentrations that, when surpassed, can affect the population's health, safety and well-being, besides causing damage to fauna and flora and the environment in general (CONAMA, 2005).

Aquatic environments have been highly polluted in function of effluent discharge of diverse origins. Treated or not, these can be domestic, mining and industrial effluents

Send correspondence to Edimar O. de Campos-Junior. Laboratório de Citogenética, Departamento de Genética e Bioquímica, Campus Umuarama, Avenida Pará 1720, 38.400-902 Uberlândia, MG, Brazil. E-mail: edimarcampos@yahoo.com.br. or water run-off in agricultural areas (Köck-Schulmeyer et al., 2013) that commonly contain contaminating agents such as heavy metals, aromatic polycyclic hydrocarbons and various agricultural chemicals (Demarini et al., 1996). These pollutants have adverse effects on human health and on other organisms that inhabit or use water resources (Isidori et al., 2003). Thus, using biomonitoring programs for environmental quality control is necessary because it contributes important information on potential risks to the environment and biota.

Magalhães and Ferrão-Filho (2008) suggested that the individual response of an organism is a good indication of environmental disturbances, because responses to stressful agents and contaminants occur at biochemical, cellular and physiological levels in an integrated manner. They can be analyzed before these effects become manifest in populations, communities and ecosystems, so they are a good alternative to prevent/anticipate more serious damage to the environment (Bortolotto et al., 2009).

In this sense, a widely used approach is to measure environmental disturbances by means of physiochemical analyses that provide data about pollution levels. However, such analyses are strictly quantitative in terms of compound levels, but are not sufficient to indicate possible risks 
for the biota. Hence, being a methodology that lacks complements to guarantee efficiency in environmental quality analysis (Dalzell et al., 2001), it is necessary to also analyze and quantify polluting activities and sources possibly related to genotoxic effects (Grant, 1982).

A viable alternative is to use plant biomonitoring to assess physicochemical factors and their correlations with chromosomal alterations/aberration frequencies, in addition to mitotic events (Monarca et al., 1999). The plant genus Tradescantia has become established as a widely used system to show genetic damage and is considered a model in this context (Misík et al., 2007).

Genetic alterations that occur in Tradescantia can be detected by analyzing chromosome aberrations/breaks in germinated cells. These can be micronuclei (MN) that are portions of chromatin close to the nucleus, derived from acentric chromosomes, induced by clastogenic (chromosome breaks) and aneugenic effects that induce aneuploidy or abnormal segregation (Almeida Neto et al., 2005; Mielli et al., 2009), caused by agents that may be present in different environments such as water, air and soil (Gopalan, 1999; Majer et al., 2005).

The Tradescantia micronucleus test (TRAD-MCN) is one of the most used assays to reveal genotoxic and/or carcinogenic effects in higher organisms. The basis of this test is the formation of micronuclei derived from chromosome breaks that occurred during meiosis, i.e. the pollen grain formation phase of Tradescantia spp. flowers (Pereira et al., 2013).

For more than three decades, data and results obtained from experiments with Tradescantia have been comparable, clear and reliable. The TRAD-MCN has many advantages, because it is a low-cost and very versatile method that makes it suitable for application in developing countries (Grant, 1994). As a biological monitoring method it is employed to complete the results of physicochemical monitoring, because it reveals in vivo effects caused by pollutants present in the environment. The aim of the present study was to use the micronucleus test with Tradescantia pallida (Rose) D.R. Hunt var. purpurea to biomonitor the water quality at eight sites along three water courses (Mumbuca creek and the Lambari and Perdizes rivers) to reveal human actions in the town of Monte Carmelo, Minas Gerais, Brazil.

\section{Material and Methods}

\section{Sampling sites}

The town of Monte Carmelo, MG, Brazil, is in the region of the Upper Paranaíba hydrographic basin (South $18^{\circ} 44^{\prime} 5^{\prime \prime}$; West $\left.47^{\circ} 29^{\prime} 47^{\prime \prime}\right)$ of the State of Minas Gerais, Brazil. The last demographic census reported that it has 45.772 inhabitants and a total area of $1.343 .035 \mathrm{~km}^{2}$ (IBGE, 2010). It is in a predominantly Cerrado biome with some areas of Atlantic Rainforest. The climate is of the Aw and Cwa type in the Köppen classification, with warm, wet summers from November to April and a cool dry winter from May to October (EMBRAPA, 2004). The main uses of the water resources in this town are: irrigation, animal drinking, public supply and human consumption, and industrial use (IGAM, 2009).

Water was collected following the model proposed by the São Paulo State Environmental Company (CETESB, 2011). Water was collected at the beginning of July 2014 on a single day. The points monitored (Figure 1) for each water resource were:

Mumbuca creek - M1: close to the headwaters (geographical coordinates: $18^{\circ} 44^{\prime} 19.60^{\prime \prime} \mathrm{S}$ and $47^{\circ} 29^{\prime} 47.40^{\prime \prime}$ W); M2: urban environment (geographical coordinates: $18^{\circ} 43^{\prime} 25.10^{\prime \prime} \mathrm{S}$ and $47^{\circ} 29^{\prime} 40.10^{\prime \prime} \mathrm{W}$ ); M3: urban environment (geographical coordinates: $18^{\circ} 42^{\prime} 31.90^{\prime \prime} \mathrm{S}$ and 47²9’37.80” W).

Lambari river - $L 1$ : close to the headwaters in a rural environment (geographical coordinates: $18^{\circ} 43^{\prime} 19.60^{\prime \prime} \mathrm{S}$ and $47^{\circ} 28^{\prime} 29.10^{\prime \prime} \mathrm{W}$ ); L2: rural environment (geographical coordinates: $18^{\circ} 42^{\prime} 10.30^{\prime \prime} \mathrm{S}$ and $47^{\circ} 28^{\prime} 27.70^{\prime \prime} \mathrm{W}$ ).

Perdizes river - $P 1$ : rural environment (geographical coordinates: $18^{\circ} 39^{\prime} 48.70^{\prime \prime} \mathrm{S}$ and $47^{\circ} 29^{\prime} 14.30^{\prime \prime} \mathrm{W}$ ); $P 2$ : highway perimeter in front of the municipal landfill (geographical coordinates: $18^{\circ} 40^{\prime} 30.40^{\prime \prime} \mathrm{S}$ and $47^{\circ} 28^{\prime} 7.10^{\prime \prime}$ $\mathrm{W})$; P3: rural environment behind the municipal landfill (geographical coordinates: $18^{\circ} 41^{\prime} 48.10^{\prime \prime} \mathrm{S}$ and $\left.7^{\circ} 26^{\prime} 57.30 ” \mathrm{~W}\right)$.

\section{Water quality index (WQI)}

The water courses in the Paranaíba river basin are classified as class 2 according to CONAMA Resolution number 357 of 2005 for freshwater classification. Data from other analytical segments (physicochemical parameters determination) were obtained from data supplied by the Minas Gerais Water Management Institute (IGAM). According to the IGAM, the following concepts are defined
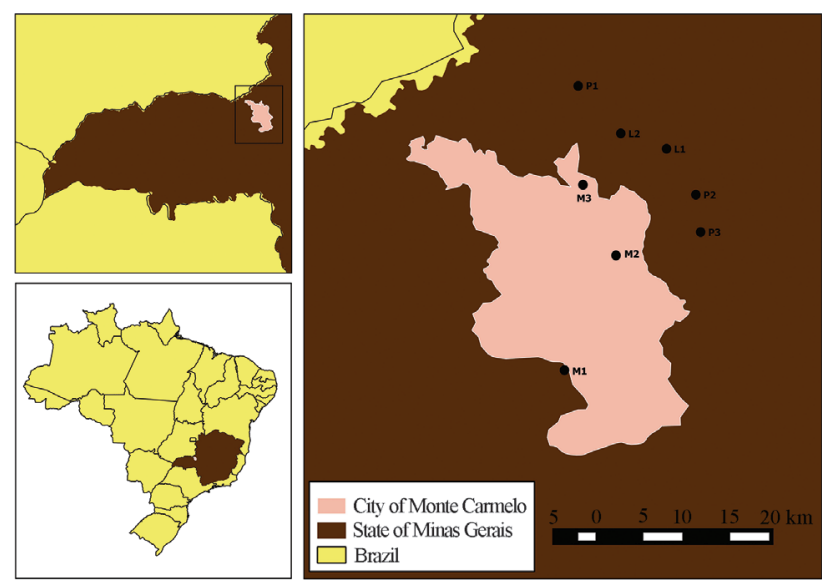

Figure 1 - Water collection sites located in the town of Monte Carmelo, Minas Gerais, Brazil. Mumbuca creeck (sites M1, M2 and M3), Lambari river (sites L1 and L2) and Perdizes river (sites P1, P2 and P3). 
according to the weighting of the parameters for water quality: Excellent $(90<\mathrm{IQA} \leq 100)$, Good $(70<\mathrm{IQA} \leq 90)$, Medium $(50<\mathrm{IQA} \leq 70)$, Poor $(25<\mathrm{IQA} \leq 50)$ and Very bad $(0<\mathrm{IQA} \leq 25)$. Concerning the data for the water quality index (WQI) obtained from the IGAM, a decrease in quality in the aquatic environments was inferred in the short term for the town under study. According to IGAM $(2011,2012)$ the surface quality of the water courses, generally, was considered Medium with little contamination by diverse toxic agents in 2011 and 2012, but was classified the next year for the same parameters as being of Poor surface quality and with medium contamination by diverse toxic agents.

\section{Preparation of Tradescantia and treatment procedure}

Tradescantia pallida plants used in the present study were grown in a greenhouse at the Fundação Carmelitana Mário Palmério - FUCAMP, following a protocol proposed by Ma et al. (1994). The ambient temperature was kept between $16^{\circ} \mathrm{C}$ at night and $26^{\circ} \mathrm{C}$ during the day, and the relative humidity was controlled at around $60-80 \%$. A $16 \mathrm{~h}$ daily photoperiod was applied to induce flowering. The plants were grown in $1 \mathrm{~L}$ pots adapted for the exposition method. Fertilization, irrigation and the spontaneous mutation rate for the plant stock were systematically controlled. Producing cuttings from the same plant guaranteed the isogenicity of the samples.

The bioassay was performed following the recommendations given by Ma (1983) with modifications. Formaldehyde at $0.2 \%$ was used as positive control, and treatments with Hoagland's solution were used as negative control. Commercial plant substrates were used and vermiculite (Bioplant, Minas Gerais, Brazil).

According Ma et al. (1994), flowerbeds with at least 15 plants were used for the experiment per study site, including the positive and negative controls. Stems measuring $15 \mathrm{~cm}$ in length with young flowers were cut and placed in Hoagland's solution (Hoagland and Arnon, 1950) for $24 \mathrm{~h}$ for acclimation, followed by treatment for $24 \mathrm{~h}$ in water samples collected at the eight sampling points, or the control solutions, respectively. Subsequently the plants were placed in Hoagland's solution for $24 \mathrm{~h}$ to recover for the subsequent TRAD-MCN experiment.

After the acclimation, treatment and recovery steps, young flowers were taken from the stems and immediately fixed in Carnoy solution (3:1 ethanol and glacial acetic acid) for $24 \mathrm{~h}$ and then preserved in 70\% ethanol until the time of analysis. Anthers collected from the buds were mashed with a glass stick on a microscope slide and a drop of acetic carmine was added for staining. They were mashed and cleaned (discarding the anther fragments) and the slide covered with a cover slip and quickly heated to $80^{\circ} \mathrm{C}$ to fix the stain on the TETRADS. Micronucleus frequencies were calculated as the number of micronuclei per
100 tetrads analyzed. For each monitored site, 20 flower buds with pollen grain cells in the tetrads state were used. Five slides were produced for each site, and 300 tetrads per study site were assessed for the presence of micronuclei under a light microscope with 400 times magnification (Ma et al., 1994).

\section{Statistical analysis}

Analysis of variance (ANOVA) followed by a Tukey post hoc test was used to determine the significance of differences among the evaluated sampling points (CallegariJacques, 2006), with $\mathrm{p} \leq 0.05$ considered statistically significant.

\section{Results and Discussion}

The micronucleus frequency at all water sample points was significantly higher when compared to the respective negative control (ANOVA, Tukey, $\mathrm{p}<0.05$ ). The data presented in Table 1 show increase in micronucleus frequency at all the points analyzed, reflecting an increase in the genotoxic potentiality along the copa water courses. Studies by Costa et al. (2014) emphasized the decrease in water quality in function of domestic and industrial effluent discharge along the course of a river, regardless of its relief.

Table 2 shows increase in parameters over three years that negatively influenced the municipal WQI and discharge of sewage is postulated as a possible pollutant source (IGAM, 2013). The decrease in the quality in the aquatic environments, confirmed by the biological parameters used, can be further corroborated by other parameters (Table 2).

Regarding the Perdizes river, a municipal landfill is located exactly between sites P2 (before treated leachate discharge) and P3 (after treated leachate discharge). Leachate formation is among the great problems inherent to land-

Table 1 - Micronucleus frequency at the sampling points in the Paranaíba river hydrographic basin, Monte Carmelo, MG, Brazil.

\begin{tabular}{lc}
\hline Collection sites & Frequency of MN/100 cells \pm SD \\
\hline Negative Control & $2.4^{\mathrm{a}} \pm 1.14$ \\
L1 & $13.60^{\mathrm{b}} \pm 1.78$ \\
L2 & $14.2^{\mathrm{b}} \pm 2.96$ \\
M1 & $6.6^{\mathrm{b}} \pm 1.34$ \\
M2 & $8.8^{\mathrm{b}} \pm 2.49$ \\
M3 & $13.8^{\mathrm{b}} \pm 2.58$ \\
P1 & $8.2^{\mathrm{b}} \pm 1.74$ \\
P2 & $7.2^{\mathrm{b}} \pm 1.48$ \\
P3 & $10.6^{\mathrm{b}} \pm 1.81$ \\
Positive control & $24.4^{\mathrm{c}} \pm 2.07$ \\
\hline
\end{tabular}

Different letters indicate statistically significant differences among MN frequencies (ANOVA, Tukey test, $\mathrm{p}<0.05$ ). 
Table 2 - Parameters above the legal limit, according to the Brazilian normative resolution (Minas Gerais, 2008) in percentage, in the Paranaíba river hydrographic basin in Monte Carmelo, MG, Brazil.

\begin{tabular}{lcccc}
\hline Parameters & Violation percentage (\%) & \multicolumn{3}{c}{ Sampling } \\
\cline { 3 - 5 } & & 2011 & 2012 & 2013 \\
\hline Biochemical oxygen demand & 72 & 2.00 & 3.10 & 8.60 \\
Escherichia coli & 15900 & - & - & $>160000$ \\
Total iron & 177 & 0.37 & 0.18 & 0.83 \\
Total phosphorus & 640 & 0.19 & 0.25 & 0.74 \\
Manganese & 13 & 0.05 & 0.06 & 0.11 \\
Waterborne ammonia & 85 & 1.53 & 2.08 & 6.86 \\
Dissolved oxygen & 85 & 6.70 & 4.80 & 2.70 \\
Surface-active substances & 106 & $<0.10$ & 0.39 & 1.03 \\
\hline
\end{tabular}

Source: IGAM (2013).

fills. Leachate is a dense, dark-colored liquid with an unpleasant odor that has varied physicochemical composition due to the state of decomposition of the residues and its original constituents (Tavares BFD, 2011, Thesis, Engenharia Ambiental na Escola Politécnica, Universidade Federal do Rio de Janeiro, Rio de Janeiro). After aerobic and anaerobic treatment, leachate is discharged directly into this watercourse, but even after treatment, some parameters are still above the tolerable limit (Table 3 ) and give a poor WQI for both treated leachate (WQI - 25.21) and sampling point $\mathrm{P} 3(\mathrm{WQI}=35.76)$. Table 3 shows six parameters obtained by physicochemical analyses. These parameters present values at site $\mathrm{P} 3$ above the desirable limit postleachate and sulfide treatment, in accordance with a Brazilian normative resolution (CONAMA, 2005).

The genotoxicity of the tested samples, especially in the Mumbuca creek, can be attributed to the management of effluents from the town, which directs all the residues to the sewage treatment station that was recently built. Currently, this facility does not have the capacity to meet all the needs of the town, which leads to irregular discharge of effluents into the watercourse (DMAE, 2014). Thus, as was shown by the TRAD-MCN test, effluents of various origins (domestic, industrial and pluvial) can mix and become complex, causing genotoxic potential for the water samples taken at the study sites.
As mentioned previously, irrigation is among the main activities using water resources in the municipality. Livestock rearing and agriculture are the main economic activities in the municipality. According to IBGE (2012a,b), coffee production (Coffea arabica L.) was over 29 tons in 2012, and there are about 56,000 heads of cattle in the area. In this sense, over time, the fragmentation of local ecosystems becomes inevitable, especially by coffee monocultures situated in regions close to watercourses. The Lambari and Perdizes rivers are close to the areas planted mainly with coffee, among other crops, along their courses, including in the area of the sample points of the present study. As pointed out by Köck-Schulmeyer et al. (2013), water run-off that contains agricultural chemicals may damage the nearby watercourses. The use of agricultural chemicals is routine in coffee plantations, therefore, as indicated by Sanches et al. (2003), the use of pesticides implies environmental contamination, especially of surface water bodies and underground water sheets, as well as an increase in fish and bird mortality and food contamination. Genotoxicity at these points of the watercourse can be attributed for the most part to the use of agricultural chemicals and the inappropriate effluent discharge from rural properties.

For the Perdizes river there is a prevalence of undesirable values for sulfides at site P3, after the discharge point

Table 3 - Physiochemical parameters of site P2, treated leachate, and site P3.

\begin{tabular}{lccc}
\hline Parameter (unit) & P2 & Leachate & P3 \\
\hline $\mathrm{pH}(\mathrm{UpH})$ & 6.7 & $9.2^{*}$ & 5.4 \\
Dissolved oxygen $(\mathrm{mg} / \mathrm{L})$ & 7.35 & $5.15^{*}$ & 7.43 \\
Biochemical oxygen demand $(\mathrm{mg} / \mathrm{L})$ & 25.33 & $1.375 .49^{*}$ & 108 \\
Sulfide $(\mathrm{mg} / \mathrm{L})$ & 0.11 & $1.22^{*}$ & $1.05^{*}$ \\
Cadmium (mg/L) & $<0.2$ & $0.23^{*}$ & $<0.2$ \\
Coliforms (NMP/100 mL) & 700 & $2476^{*}$ & 576 \\
\hline
\end{tabular}

*Substances above the desirable limit (CONAMA resolution Nr. 357 of 2005). 
where the treated leachate enters the river body and is diluted. This is possibly a reflection of the methodology used in the treatment, because by anaerobic treatment, metals may precipitate in the form of metallic sulfides. The biological treatment used generally leads to improvement in the parameters for untreated leachate, but the high concentration of some metals, especially heavy metals, can lead to biological inhibition, so that chemical precipitation should be associated with the biological treatment (Iwai CK, 2005, Master's thesis, Faculdade de Engenharia, Universidade Estadual Paulista, Campus Bauru).

The WQI data, specifically those for treated leachate and at site P3, suggest that the biological treatment used should undergo reconsideration, as alone it does not present enough improvement in the leachate parameters, as required by the environmental agencies. Crude leachate samples were not assessed because they have recognized genotoxic properties (Obidoska and Jasinska, 2008). The treated leachate value was $\mathrm{WQI}=25.21$, which represents a value between Poor and Very bad on the WQI classification scale by IGAM, reaffirming the need to associate other methodologies for leachate treatment, as proposed by Nunes et al. (2011).

The first collection site on the Perdizes river (P1), did not differ statistically from P3. In this case, although P1 was distant and possibly did not suffer directly from the influence of the municipal landfill, the possibility for similar genotoxicity at both the sites can be explained generically by the proximity of this sampling site to the cropped regions, as occurs also on the Lambari river, indicating recurrent use of agricultural chemicals. As reported by Oliveira (Oliveira DA, 2010, Thesis, Instituto de Geografia, Universidade Federal de Uberlândia), the vegetation on the Perdizes river banks is little preserved and the use of agricultural chemicals is common in the surroundings of this watercourse.

In conclusion, our results suggest that in the Mumbuca creek the current situation of effluent discharge should be reconsidered by the municipal environmental authorities, seeking the improvement of the system. This should consider the variability and complexity of the existing effluents (rainfall, domestic and industrial) and the influence they have on the conservation and environmental quality of the watercourse. On the Lambari river, the observed increase in micronucleus frequency at L1 and L2 emphasizes the need to adopt environmental vigilance strategies, such as biological monitoring to assess the direct influence of agricultural chemicals at these and other sites on the stream, and to direct the effluents from rural properties in this region to the municipal treatment station. For the Perdizes river the inference is that leachate discharge negatively influences the environmental quality of the River Perdizes, especially so at the site P3.

\section{References}

Almeida Neto JX, Medeiros FPM, Melo, AJM, Silva JC and Dantas JP (2005) Avaliação do efeito mutagênico da palma forrageira (Opuntia fícus-indica Mill) através do teste de micronúcleos em medula óssea de ratos (Rattus novergicus, linhagem Wistar) in vivo. Rev Biol Ciênc Terra 5:41-50.

Bortolotto JBT, Bertoldo FZD, Silveira TM, Silvano DJ and Pitch CT (2009) Evaluation of the toxic and genotoxic potential of landfill leachates using bioassays, Environ Toxicol Pharmacol 28:288-293.

Callegari-Jacques SM (2006) Bioestatística: Princípios e Aplicações. Editora Artmed, Porto Alegre, 255 p.

Costa GM, Cassanego MBB, Petry CT, Benvenuti T, KielingRubio MA, Rodrigues MAS and Droste A (2014) Monitoramento químico e do potencial genotóxico para o diagnóstico da qualidade de corpos hídricos. Rev Bras Ciênc Ambient 32:65-74.

Dalzell DJ, Alte S, Aspichueta E, De La Sota A, Etxebarria J, Gutierrez M, Hoffmann CC, Sales D, Obst U and Christofi N (2001) A comparison of five rapid direct toxicity assessment methods to determine toxicity of pollutants to activated sludge. Chemosphere 47:535-545.

Demarini DM, Shelton ML and Bell DA (1996) Mutation spectra of chemical fractions of a complex mixture: Role of nitroarenes in the mutagenic specificity of municipal waste incinerator emissions. Mutat Res 349:1-20.

EMBRAPA (2004) Boletim de Pesquisa e Desenvolvimento: Levantamento de Reconhecimento de Média Intensidade dos Solos da Região do Alto Paranaíba, Minas Gerais. EMBRAPA, Rio de Janeiro.

Gopalan HNB (1999) Ecosystem health and human well being: The mission of the international programme on plant bioassays. Mutat Res 426:99-102.

Grant WF (1982) Chromosome aberration assays in Allium. A report of the U.S. Environmental Protection Agency GeneTox Program. Mutat Res 99:273-291.

Grant WF (1994) The present status of higher plant bioassays for detection of environmental mutagens. Mutat Res 310:175185.

Hoagland DR and Arnon DI (1950) The water-culture method for growing plants without soil. Circular n. 347. Agricultural Experiment Station, Berkeley, pp 1-39.

IGAM (2009) Monitoramento da Qualidade das Águas Superficiais da Bacia do Rio Paranaíba. Relatório Anual. IGAM, Belo Horizonte.

IGAM (2012) Monitoramento da Qualidade das Águas Superficiais no Estado de Minas Gerais, Relatório trimestral, $3^{\circ}$ trimestre de 2012. IGAM, Belo Horizonte.

Isidori M, Ferrara M, Lavorgna M, Nardelli A and Parrela A (2003) In situ monitoring of urban air in Southern Italy with the Tradescantia micronucleus bioassay and semipermeable membrane devices (SPMDs). Chemosphere 52:55-61.

Köck-Schulmeyer M, Villagrasa M, De Alda ML, CéspedesSánchez R, Ventura F and Barceló D (2013) Occurrence and behavior of pesticides in wastewater treatment plants and their environmental impact. Sci Total Environ 458460:466-476.

Ma TH (1983) Tradescantia micronuclei (Trad-MCN) test for environmental clastogens. In: Kolber A, Wong T, Grant L, Dewoskin R and Hughes T (eds) In Vitro Toxicity Testing of 
Environmental Agents, Part A. Plenum, New York, pp 191-214.

Ma TH, Cabrera GL, Chen R, Gill BS, Ssandhu SS, Vandenberg AL and Alamone MF (1994) Tradescantia micronucleus bioassay. Mutat Res 310:221-230.

Magalhães DP and Ferrão Filho AS (2008) A ecotoxicologia como ferramenta no biomonitoramento de ecossistemas aquáticos. Oecol Bras 12:355-381.

Majer BJ, Grummt T, Uhl M and Knasmuller S (2005) Use of plant bioassays for the detection of genotoxins in the aquatic environment. Acta Hydrochim Hydrobiol 33:45-55.

Mielli, AC, Matta MEM, Nersesyanc A, Saldiva PHN and Umbuzeiro GA (2009) Evaluation of the genotoxicity of treated urban sludge in the Tradescantia micronucleus assay. Mutat Res 672:51-54.

Minas Gerais (2008) Deliberação Normativa n. 01 maio de 2008. Conselho de Política Ambiental de Minas Gerais/Conselho Estadual de Recursos Hídricos, Belo Horizonte.

Misík M, Micieta K, Solenska M, Misikova K, Pisarcikova H and Knasmuller S (2007) In situ biomonitoring of the genotoxic effects of mixed industrial emissions using the Tradescantia micronucleus and pollen abortion tests with wild life plants: Demonstration of the efficacy of emission controls in an eastern European city. Environ Pollut 145:459-466.

Monarca S, Feretti D, Zanardini A, Falistocco E and Nardi G (1999) Monitoring of mutagens in urban air samples. Mutat Res 426:189-192.

Nunes EA, Lemos CT, Gavronski L, Moreira TN, Oliveira NCD and Silva J (2011) Genotoxic assessment on river water using different biological systems. Chemosphere 84:47-53.

Obidoska G and Jasinska D (2008) Phytotoxicity and potential genotoxicity of Radiowo municipal leachate. Land Reclamation 40:39-44.

Pereira BB, Campos Junior EO and Morelli S (2013) In situ biomonitoring of the genotoxic effects of vehicular pollution in Uberlândia, Brazil, using Tradescantia micronucleus assay. Ecotoxicol Environ Safe 87:17-22.

Sanches SM, Silva CHTP, Campos SX and Vieira EM (2003) Pesticidas e seus respectivos riscos associados à contaminação da água. Ecotoxicol Meio Ambiente 13:53-58.

\section{Internet Resources}

CETESB (2011) Guia Nacional de Coleta e Preservação de Amostras: Agua, Sedimento, Comunidades Aquáticas e Efluentes Líquidos. Companhia Ambiental do Estado de São Paulo, São Paulo, pp 51-58, http://www.cetesb.sp.gov.br/userfiles/file/laboratorios/publ icacoes/guia-nacional-coleta-2012.pdf (accessed 21/01/2014).

CONAMA (2005) Resolução n 357 de 17 de março de 2005, http://www.mma.gov.br/port/conama/legiabre.cfm?codlegi $=459($ accessed 20/01/2014).

DMAE (2014) Descrição Funcional do Sistema do Esgotamento Sanitário - Monte Carmelo, http://dmae.montecarmelo.mg.gov.br/servicos/esgoto (accessed 20/01/2014).

IBGE (2010) Minas Gerais, Monte Carmelo, Infográficos: dados gerais do município, http://cidades.ibge.gov.br/painel/painel.php?codmun = 314310 (accessed 20/01/2014).

IIBGE (2012a) Minas Gerais, Monte Carmelo: Produção Agrícola Municipal: Lavoura Permanente, http://cidades.ibge.gov.br/xtras/temas.php?lang=\&codmun $=314310 \&$ idtema $=122 \&$ search $=$ minas-gerais monte-carmelo producao-agricola-municipal-lavoura-permanente-2012 (accessed 15/10/2014).

IBGE (2012b) Minas Gerais, Monte Carmelo: Pecuária, http://cidades.ibge.gov.br/xtras/temas.php?lang=\&codmun $=314310 \&$ idtema $=121 \&$ search $=$ minas-gerais monte-carmelo pecuaria-2012 (accessed 15/10/2014).

IGAM (2013) Qualidade da Água, Mapa de Qualidade das Águas, Relatórios, Media anual da Bacia do Rio Paranaíba. http://www.igam.mg.gov.br/images/stories/qualidade_aguas/2014/mapas/2013-a4-pn-3t.pdf (accessed 15/10/2014)

WHO (2011) Guidelines for Drinking-Water Quality. Fourth edition. World Health Organization, Programmes, Water Sanitation Health, http://www.who.int/water_sanitation_health/publications/2011/dwq_guidelines/en/index.'̄tml (accessed 20/01/2014).

Associate Editor: Catarina S. Takahashi

This is an open-access article distributed under the terms of the Creative Commons Attribution License (type CC-BY), which permits unrestricted use, distribution and reproduction in any medium, provided the original article is properly cited. 